\title{
The Differences of Influence Segmented Method and Whole Method to Improve the Basic Techniques of Badminton
}

\author{
$\operatorname{Zarwan}^{1 *}$, Arsil $^{1}$ \\ ${ }^{1}$ Faculty of Sport Science, Universitas Negeri Padang, Indonesia \\ *Corresponding author. Email: fikzarwan@gmail.com,
}

\begin{abstract}
The purpose of this research is to increase the effectiveness of badminton training of elementary students. The method used in this research is quasi-experimental,pretest-posttest control group design,using two independent variables and one dependent variable. The independent variables is the segmented and whole method. The dependent variable is the basic techniques ability of badminton players. The result of the research can be seen as follows: The average increase in segmented method is 23.57 and the average increase in whole method is 36.57. Based on the results of data analysis it can be concluded that : (1) segmented method have an influence on the increase in the basic techniques of playing badminton. (2) whole method also influences the basic techniques of playing badminton. (3) There are significant differences betweensegmented method andwhole method in which the whole method gives a greater influence.
\end{abstract}

\section{Keywords: Segmented Method, Whole Method, Basic Techniques of Badminton}

\section{INTRODUCTION}

Physical exercise is a part of everyday activity that is important for human beings and useful to obtain physical and spiritual healthiness. Among the growing sport branches in Indonesia, badminton is one of the most popular sports in the community. Badminton is favored by many old and young people, both men and women, especially in Indonesia. This is because badminton is not only easy to play but also is easy to get the equipments. An understanding of the values of badminton sport will be useful for the players, especially the existence of its advantages associated with physiological-anatomical development as well as physiological and sociological development. The existence of badminton sport in the midst of the rapid development of other sports activities should be the attention of various parties.

"To gain the optimal achievement, there are 4 (four) components to be considered, namely, the physical condition, technique, tactics and mental" [1]. In addition to these four components, there is the most important thing in a process of achievement, namely coaching achievements done since at early age. Therefore, it is necessary to do coaching since primary school age. "Sports coaching at the club or school level, generally starts from an early age period between 6-12 years of age" [2]. Its existence as a coaching layer that plays a role to perpetuate the regeneration process becomes very important, because clubs and schools are the initial center for athlete coaching. Coaching the early-age athletes is one of the most fundamental strategies in an effort to improve sport achievement".

Another factor that greatly affects the success of achievement is the ability of one's technique. "Technique is the most important element in achievement" [3]. The problem that occurs is how to train good techniques for primary school age athletes. To train the athletes at this age range, the trainer should be able to choose the appropriate method so that the child does not easily get bored in training. Of the many training methods that can be used to improve the basic techniques of badminton, the authors assume that the elementary and global method are considered as the most appropriate method to use for elementary school aged children. Therefore, the authors are interested to conduct research to see the effect given by the elementary and global method in improving the basic techniques in playing badminton.

\section{Elementary Method}

Segmented or elementary training method is a way of doing technique exercises in sports done part by part or sorted into every part included in the technique exercise. " method is a way of practice viewing that an exercise can be given according to its parts" [4]. This exercise is a complementary unity in the form of simple sequence of motion. The motion exercises are given from the easy one to the more difficult and complex level. Each of the elements of movement must be mastered before proceeding to the next movement. It can be explained through example such when applying forehand drive, it 
requires correct movement technique. It should pay more attention to the position of player's feet, body and both hands while holding the racket, as well the position of the ball to be hit, the contact point, and its follow troughs. These sections should be studied separately, then finally the child can move with correct coordination. In other words, children should first be trained on movements that lead to the intended movement. Once all the elements that support the forehand drives are done correctly then it may be said that the forehand drive movement is done correctly. "method is used in fundamental motor technique lessons, then the teaching procedure would be as the following: the student receives instructions on the task of the first movement (ready position of foot movement), after the first movement is mastered then they receive the second movement practice instruction (backswing and forward swing), then it is continued by giving the next instruction that is how the ball is hit into the racket and follow-up movement (follow strough)" [5]. Each element of the movement must be held so that the movement will not interfere other movements.

The elementary or segmented method has several advantages, (a) the child keenly appreciates and implement each element of movement in one technique, (b) if the movement structure is complex, then it is possible to obtain maximum result. The segmented method is easier and faster to learn and the child will feel more satisfied once they are instructed to do the whole movement. The advantages of the exercise by using the part method in detail, namely: "(a) the students will master the phases of an existing technique, (b) the students will get better movement quality, (c) ) this method make the students to understand easily the concepts of all techniques, (d) the mistakes in movement will be more easily corrected ".

Some opinions about the advantages of segmented method are stated by some experts. It can be said that elementary or part method is a technique training method provided by dividing each element of movement into the form of exercise. That is, the exercise provided separates each section so that it is not done at once. In this study, what will be done is to provide practice by sorting a technique into sections ranging from the simplest level to the most complex level.

\section{Whole Method}

The global method is based on Gestalt theory. This theory says that the whole method principle is important in the process of motor skill learning. This theory introduces an organizational approach to stimulus-response (S-R). Stimulus response is organized parts in a whole form. Method is based on Gestalt's theory which emphasizes that the whole is an important, global principle more than the sum of the parts, whereas its part implies in relation to the whole.

General that learning materials should be studied as a whole not part by part. the process of sports learning is emphasized on the exercise as a whole. Meanwhile, method is a way to teach motor skills by teaching the whole series of motions at once.
The global method is given as a whole unit which is not divided down into several techniques. In implementing global method, children are more active in activities and are expected to be better able to recognize and develop their full learning and achievement capacities. This technique indeed emphasizes more on students' dominant activity regardless the role of teachers. Regardless any method that will be used, before students learn new basic techniques, the concept of basic technique should be shown and demonstrated in advance to the students so they get a clear picture of what will be done later.

The whole method has several advantages. the global method are: "(a) integration and coherence of the basic technique will be maintained, (b) practice global will be more efficient in terms of time, (c) global practice will motivate children. Furthermore Puradisastra (1980) argues that the global method shows advantages when it is used in teaching and learning, including: (a) for smart people, the global way is more profitable and faster, (b) the advantages of the whole method will increase if it is often used, (c) understanding the whole method in higher materials is more advantageous, (d) meaningful materials is suited more to global means, (e) in the longest and shortest materia, the more global way is much more profitable".

The whole method is the method given to the child as a whole. The movement techniques are given as a whole without being separated, so the child can do those movements in a complex way. While doing the exercises in a global way, the athlete performs all forms of technique and the trainer will correct any mistakes made in all aspects of the technique. In this study, the global method is given in the form of a technical movement intact without being divided into several parts.

\section{Badminton Basic Techniques Grip}

How to hold a badminton racket is actually quite easy, because of its form or its handle? Nevertheless, in playing badminton, the correct way to grip the racket will advantageously help the player. The mastery of the correct technique to grip the racket will allow athletes to make a punch and will also produce a right-on-target hit. For beginners, the grip techniques mastery is necessary, because if this technique is not properly controlled, it will be difficult to repair or correct it in the future, and consequently will affect the accuracy of the blow. It is suggested to hold the racket casually. If it is grabbed too strong, it will deplete the hand power of those who hold the racket. Types of racket grip that must be known, namely "gablak kasur", forehand grip, backhand grip and combination grip.

\section{Service}

"Service is the first hit as game opening and the first attack on the opponent. Service is an important blow that begins a game" [6]. The importance of this techniques is proved that the game will not be begun until the first blow (service) is done and only those who serve will get point or score. For that reason, the service needs to be mastered by 
a badminton player. There are several types of services that need to be mastered, they are: short service and long service done through forehand and backhand.

\section{Lob}

"Lob is a blow aiming at flying the shuttlecock as high as possible in order to fall on the back of the opposing field. Lob can be done from the top of the head (overhead) or from under (underhand) either through forehand or backhand" [6]. Based on its characteristics, a player who often uses lob punch should be supported by great energy and high stamina. This blow can be used to attack and also to defend, and also to slow the tempo of the game so as to be able to change the position. The lob punch is suggested to be directed in various ways, straight, crossed to the left or right behind the opponent's field.

\section{Smash}

"Smash is the key to turn off the shuttlecock on the side of the opponent. The initial movement for smash is almost the same as lob. Smash is an overhead blow (top) that is directed down and done with full force" [6]. This punch is identical as punch attack because the main goal is to turn off your opponent. Smash blow is a form of hard blow that is often used in badminton games. The characteristics of this blow are; hard, the pace of the road is fast moving to the field, so this punch requires leg, shoulders and arms muscle strength,and the flexibility of the wrist and coordination of harmonious gestures. In the practice of the game, smash blows can be done in standing or jumping position (King Smash).

\section{METHODOLOGY}

\section{Types of Research}

The type of research was quasi experiment by using elementary/segmented method and global/whole method as independent variables and basic technique of playing badminton as dependent variable. The population in this study was the students who took extracurricular badminton in equal to 14 people. Since the population in this study was small, the entire population was used as a sample (total sampling).

\section{RESULT AND DISCUSSION}

\section{Pre Test using Elementary/Segmented Method}

From the result of measuring the sample's ability to apply badminton basic technique, it was found that the highest score was 66 and the lowest score was 31. Based on the smash ability data, it was obtained that the average value (mean) was 48.43 , median was 47 , and standard deviation was 13.66. For more details, it can be seen in the table below:
Table 1. Frequency Data Distribution of Badminton Basic Technique Ability.

\begin{tabular}{|c|c|c|c|}
\hline Interval Class & Fa & Fr (\%) & Classification \\
\hline$>60.53$ & 2 & 28.57 & Very good \\
\hline $50.27-60.53$ & 1 & 14.29 & Good \\
\hline $40.01-50.26$ & 2 & 28.57 & Fair \\
\hline $29.76-40.00$ & 2 & 28.57 & Poor \\
\hline$<29.76$ & 0 & 0.00 & Very poor \\
\hline Total & 7 & 100 & \\
\hline
\end{tabular}

Based on the calculation shown in table 1 , it can be seen that 2 students $(28.57 \%)$ were in very good category, and 1 student (14.29\%) was in good category, 2 students $(28.57 \%)$ were in fair category, 2 students $(28.57 \%)$ were in poor category and no students $(0.00 \%)$ was in very poor category.

\section{Pre Test using Whole Method}

From the result of measuring the sample's ability to apply badminton basic technique, it was found that the highest score was 48 and the lowest score was 37 . Based on the smash ability data, it was obtained that the average value (mean) was 41.86 , median was 43 , and standard deviation was 4.02 . For more details, it can be seen in the table below:

Table 2. Distribution Frequency Data of Badminton Basic Techniques Ability using Whole Method.

\begin{tabular}{|c|c|c|c|}
\hline Interval Class & $\mathrm{Fa}$ & $\mathrm{Fr}(\%)$ & Classification \\
\hline$>60.53$ & 0 & 0.00 & Very good \\
\hline $50.27-60.53$ & 0 & 0.00 & Good \\
\hline $40.01-50.26$ & 4 & 57.14 & Fair \\
\hline $29.76-40.00$ & 3 & 42.86 & Poor \\
\hline$<29.76$ & 0 & 0.00 & Very poor \\
\hline Total & 7 & 100 & \\
\hline
\end{tabular}

Based on the calculation shown in table 2, it can be seen that there are no students $(0.00 \%)$ who was in very good category and good category, 4 students (57.14\%) were in fair category and 3 students $(42.86 \%)$ were in poor category and no students $(0.00 \%)$ was in very poor category.

\section{Post Test using Segmented Method}

From the result of measuring the sample's ability to apply badminton basic technique, it was found that the highest score was 96 and the lowest score was 48. Based on the smash ability data, it was obtained that the average value (mean) was 72 , median was 68 , and standard deviation was 19.03. For more details, it can be seen in the table below: 
Table 3. Distribution Frequency Data of Badminton Basic Techniques Ability.

\begin{tabular}{|c|c|c|c|}
\hline Interval Class & $\mathrm{Fa}$ & $\mathrm{Fr}(\%)$ & Classification \\
\hline$>60.53$ & 5 & 71.43 & Very good \\
\hline $50.27-60.53$ & 1 & 14.29 & Good \\
\hline $40.01-50.26$ & 1 & 14.29 & Fair \\
\hline $29.76-40.00$ & 0 & 0.00 & Poor \\
\hline$<29.76$ & 0 & 0.00 & Very poor \\
\hline Total & 7 & 100 & \\
\hline
\end{tabular}

Based on the calculation shown in table 3 , it can be seen that 5 students $(71.43 \%)$ were in very good category, 1 student $(14.29 \%)$ was in good category and 1 person $(14.29 \%)$ was in fair category and no students $(0.00 \%)$ was in poor category and in very poor category.

\section{Post Test using Whole Method}

From the result of measuring the sample's ability to apply badminton basic technique, it was found that the highest score was 93 and the lowest score was 58. Based on the smash ability data, it was obtained that the average value (mean) was 78.43 , median was 83 , and standard deviation was 13.41. For more details, it can be seen in the table below:

Table 4. Frequency Distribution Data of Badminton Basic Technique Ability Using Whole Method.

\begin{tabular}{|c|c|c|c|}
\hline Interval Class & $\mathrm{Fa}$ & $\mathrm{Fr}(\%)$ & Classification \\
\hline$>60.53$ & 8 & 88.89 & Very good \\
\hline $50.27-60.53$ & 1 & 11.11 & Good \\
\hline $40.01-50.26$ & 0 & 0.00 & Fair \\
\hline $29.76-40.00$ & 0 & 0.00 & Poor \\
\hline$<29.76$ & 0 & 0.00 & Very poor \\
\hline Jumlah & 9 & 100 & \\
\hline
\end{tabular}

Based on the calculation shown in table, it can be seen that 8 students $(88.89 \%)$ were in very good category and 1 person $(11.11 \%)$ was in good category and no students $(0.00 \%)$ was in fair, poor and very poor category.

\section{Discussion}

Based on hypothesis testing that has been described above, it can be seen that the average data in group of segmented method is greater than the average initial data score. based on test of difference, it is known that t count is larger than the table then the hypothesis stating that there is significant influence given by segmented method to the improvement of basic techniques of playing badminton can be accepted empirically. The method of segmented or section exercises is a way of doing exercises in sports that are done part by part or the exercises are divided into several parts that exist in a technique. Method contains a division or decomposition of a movement into functional elements of motion. It is based that the learned part movements can be incorporated into a complex (whole) motion without losing the quality of the movement. Implementation of this method requires the decomposition or grouping of a sporting engineering process into several functional parts. The implementation of segmented method divides movement from the easiest level to the most difficult level, so that students will be easier to learn badminton techniques.

The second hypothesis in this research is accepted empirically. It was known that tcount is bigger than ttable and mean of final data is bigger than the average of initial data. The global method departs from the whole movement of a technique and tries to discover / get the technique through the learning process. The global method is a way of teaching basic motor techniques by teaching the whole series of motions at once. Some of the advantages of implementing global method, positive aspects of the global method are: 1. Learners quickly know the idea of a game, 2. Learners quickly know the function of each technique, 3. Learners can learn the techniques at once, 4. Learners can feel the actual play, 5. Fewer learners can learn directly about the techniques and strategies of play, 6 . Intensity of motor activity tend to be higher, 7. Learners can learn directly about problem and solving (problem solving), 8. Learners can learn directly about the problem of role and function in group, 9. Learners can learn to cooperate, 10. Motivation to practice will tend to be higher. Through whole method, the children will be more motivated because this exercise is not boring so that children can learn more leverage. Thus, whole method can provide the maximum effect.

The third hypothesis in this study is there is significant difference between the segmented method and whole method in improving the basic technique of playing badminton. In this hypothesis, it was seen the real difference from the effects given by both the exercise method. Based on the results of hypothesis testing that has been described previously, it can be seen that the two method of exercise are equally able to provide a significant effect on improving the physical condition of students, and based on the magnitude of the average value, it can be seen that the effects provided by the whole method is greater than segmented method. This can happen because the whole method is a thorough method whereby the badminton play will be done by the child intact without being divided into sections so that the exercise tends not to be boring. Hence, the child will prefer to follow the training process.

\section{CONCLUSION}

Based on the explanation above, it can be concluded that: Segmented method provides significant influence to the improvement of basic technique in badminton; The whole method gives significant influence on improving the basic technique in badminton; There is a significant difference showed by the segmented method and whole method by which the whole method gives greater influence.

Based on the conclusion above, the researcher suggests to the teachers and badminton trainer in elementary school to use segmented method and whole method as an effort to improve badminton basic technique at elementary school age children. 


\section{REFERENCES}

[1] Syafruddin. "Ilmu Kepelatihan Olahraga: Teori Dan Aplikasinya Dalam Pembinaan Olahraga". Padang. UNP Press. 2011. Pp 12.

[2] Ghazali. "Pengembangan Pembelajaran Teknik Dasar Bulutangkis Berbasis Multimetode Pada Atlet Usia 11 dan 12 tahun”. Jurnal Keolahragaan. Volume 4- No. 2, pp.1-2. 2016.

[3] Bompa. "Periodization, Theory And METHODOLOGY Of Training. Fourth Edition". USA:Kendal/Hunt Publising Company. 1990, pp 54.

[4] Sneyers. "Bolavoli Latihan dan Strategi Belajar Mengajar. Terjemahan Monti". Jakarta; Rosda Jaya Putra Offset. 1988, pp. 12.

[5] G. Durrwachter. "Belajar dan Berlatih Sambil Bermain. Terjemahan Agus Setiadi”. Jakarta; Grametode. 1990, PP 65

[6] Zarwan. "Bulutangkis". Padang: sukabina press. 2010, pp 6. 